\title{
Closing the Snack Bar: Developing Methods for Jackfruit Tree (Artocarpus heterophyllus Lamk.) Control in Brazil
}

\author{
Ciro José Ribeiro de Moura ${ }^{1}$ (D), Marcela Gaspar², Helena Godoy Bergallo ${ }^{3}$, \\ Ana Carolina Lacerda ${ }^{4}$, Átilla Ferreguetti ${ }^{3}$ \\ ${ }^{1}$ Universidade Federal do Rio de Janeiro - UFRJ, Rio de Janeiro/RJ, Brasil \\ ${ }^{2}$ Independent consultant, Rio de Janeiro/RJ, Brasil \\ ${ }^{3}$ Universidade do Estado do Rio de Janeiro - UERJ, Rio de Janeiro/RJ, Brasil \\ ${ }^{4}$ Universidade Federal de Lavras - UFLA, Lavras/MG, Brasil
}

\begin{abstract}
There are several techniques for the control and removal of invasive species that can be applied, and there is a demand among restoration practitioners for plant control methods. This study compared two methods for the control of jackfruit tree: mechanical method of trunk girdling and chemical method of herbicide injection into the trunk. It was evaluated both methods in terms of effectiveness in 10 plots $(80 \times 80 \mathrm{~m})$. For the chemical method, triclopyr in concentrations of $2 \%$, $6 \%$ and $8 \%$ was used. The progress of treatments was evaluated accordingly for the phytosanitary conditions. Method of trunk girdling proved to be ineffective and it had a low mortality rate $(12 \%)$. The proportion of dead trees by chemical treatment was $100 \%$. The results showed that chemical control of jackfruit trees was much faster and more effective.
\end{abstract}

Keywords: biological invasions, species control, practice management. 


\section{INTRODUCTION}

Prevention is still the best way to avoid problems arising from biological invasions (Pimentel, 2002; Richardson \& Thuiller, 2007; ISSAC, 2018). However, once the invasion process is recognized, control measures should be taken immediately to prevent further damage, as costs and control effectiveness increase over times (Moody \& Mack, 1988). The process of invasion comprises the establishment and propagation of invasive alien species (IAS); nevertheless, the lack of awareness and establishment of control strategies aggravates the problem, and inevitably leads to loss of biodiversity and biological homogenization of the landscapes (Sigg, 1998; Pyšek et al., 2012; Zenni et al., 2016). It is necessary to determine the best method according to the circumstances, i.e. the target species, degree of infestation, habitat and available labor (Rejmánek \& Pitcairn, 2002). In this sense, the efficiency of control depends on having thorough good knowledge of the biology on target species, resource availability for the establishment of programs and monitoring of the process of restoration area.

There are several techniques for the control and removal of invasive species that can be applied on a case-by-case basis, and there is a demand among restoration practitioners for a decision support tool to choose the best plant control methods (Sher et al., 2018). Management of invasive alien plants may or may not involve a combination of mechanical, chemical and biological control methods. Mechanical control can be achieved by withdrawing seedlings or cutting/girdling the trunks (Shine, 2008). For the control of invasive arboreal species, girdling is a popular technique to control invasive tree species in adulthood (Weber, 2017). However, it is common for some species resprouting from the stem base after girdling, and this requires reworking and further expenses. However, the method of seedling uprooting should be applied for trees in the juvenile phase. The use of herbicide can be an opportunity to improve the control of invasive species, especially when combined with other control techniques, such as seedling withdrawing, felling or girdling (Itou et al., 2014).

Discussions about the use of herbicides in the sphere of decision makers are scarce, and rare are those that apply operationally this type of technological resource (Sigg, 1998). This is mainly due to a lack of knowledge on the part of decision makers, who believe that the application of herbicides always poses a danger risk to environment (Myers et al., 2016). Sigg (1998) stated that, for invasive plants, the focus of the discussion on protected areas should be the risk to biological diversity, rather than the use of herbicides against aggressive invaders. In this sense, considering the risks of using this method, it is very important to determine the type and dosage of herbicide and the most efficient application method to control invasive species (Itou et al., 2014) in order to obtain a "better trade-off" between risks and benefits.

Native to south-eastern Asia, the jackfruit tree (Artocarpus heterophyllus Lamk.) in its original distribution is considered rare and very shade tolerant, in other words, a characteristic of advanced successional stages (Khan, 2004). Jackfruit tree was introduced to Brazil during the colonial period and has been spread intentionally throughout the national territory (Boni et al., 2009). In the Atlantic Forest in northeast and southeast Brazil, high densities of jackfruit tree can be observed (Abreu \& Rodrigues, 2010; Fabricante et al., 2012; Bergallo et al., 2016), and in the absence of human intervention, its population expansion may be an irreversible process. In fact, jackfruit tree alters species richness, diversity of vegetation and soils of invaded areas (Fabricante et al., 2012). This supports the assumption that such species are more abundant in the invaded area than in their original locations (Williamson \& Fitter, 1996; Hierro et al., 2005). The jackfruit tree has a series of characteristics that can be defined as an invasive species, such as a great capacity to grow and produce seeds under a variety of climatic and edaphic conditions; a large number of seeds produced per fruit; a strong ability to compete for water, light and nutrients (Ziller, 2001) and a high germination rate (Khan, 2004). In addition, many species have been reported to disperse jackfruit seeds, such as the "capuchin" monkey, Sapajus nigritus (Cáceres, 2000), the false vampire bat, Phyllostomus hastatus (Raíces et al., 2008), the spiny rat, Trinomys iheringi, and the spotted "paca", Cuniculus paca (Raíces et al., 2017).

Studies developed by the Laboratory of Mammal Ecology (Universidade do Estado do Rio de Janeiro (UERJ)) at Ilha Grande State Park showed that the influence of the jackfruit tree has caused an increase in the abundance of some mammals (Mello et al., 2015); on the other hand, a decrease in native plant species 
seed dispersal by mammals (Raíces et al., 2017). In this scenario, making a decision to establish the control of jackfruit trees at Ilha Grande State Park is in compliance with Brazilian Federal Law 9.985/2000 that established the National System of Protected Areas that prohibit the introduction and presence of non-native species in protected areas. In this context, based on existing knowledge on the use of herbicides in the control of invasive species (Sigg, 1998; Tu et al., 2001), the aim of this study was to compare two methods for the control of A. heterophyllus: the mechanical method of trunk girdling and the chemical method of herbicide injection into the trunk. In terms of effectiveness, the two methods were evaluated and compared.

\section{MATERIAL AND METHODS}

\subsection{Study area}

The study was carried out in a region covered by Ombrophylous Dense Forest (RADAMBRASIL, 1993), in Ilha Grande, an island located in the municipality of Angra dos Reis, on the southwestern coast of Rio de Janeiro State, Brazil (Figure 1). Ilha Grande is part of a group of islands and islets that characterizes the bay of the same name. It is a fragment of the coastal massif, isolated from the mainland by a channel about $2 \mathrm{~km}$ wide. The island covers about $193 \mathrm{~km}^{2}$, with a very rugged relief, comprising the "Papagaio peak" (959 m) and the "Pedra D'Água peak" (1,031 m), both being the highest points (Oliveira, 2002). More than $80 \%$ of the land area of Ilha Grande is protected by the Ilha Grande State Park (Parque Estadual da Ilha Grande (PEIG)) $\left(120.7 \mathrm{~km}^{2}\right)$ and Praia do Sul State Biological Reserve (Reserva Biológica Estadual da Praia do Sul) $\left(36 \mathrm{~km}^{2}\right)$.

When Portuguese explorers arrived in Ilha Grande in 1502, the land was exploited in different ways, such as for crops of sugarcane, cocoa and coffee (Santiago et al., 2009). Nowadays, there are no more crops, but secondary forests are prevalent on the island (Oliveira, 2002). There is no information on when jackfruit trees were introduced into Ilha Grande, but these species are found mostly on trails that have been intensely used in local history (Bergallo et al., 2016).

\subsection{Data collection}

The experiments were performed on 10 plots established in PEIG, near "Dois Rios Village" (Figure 1). According to the definition of plots where jackfruit
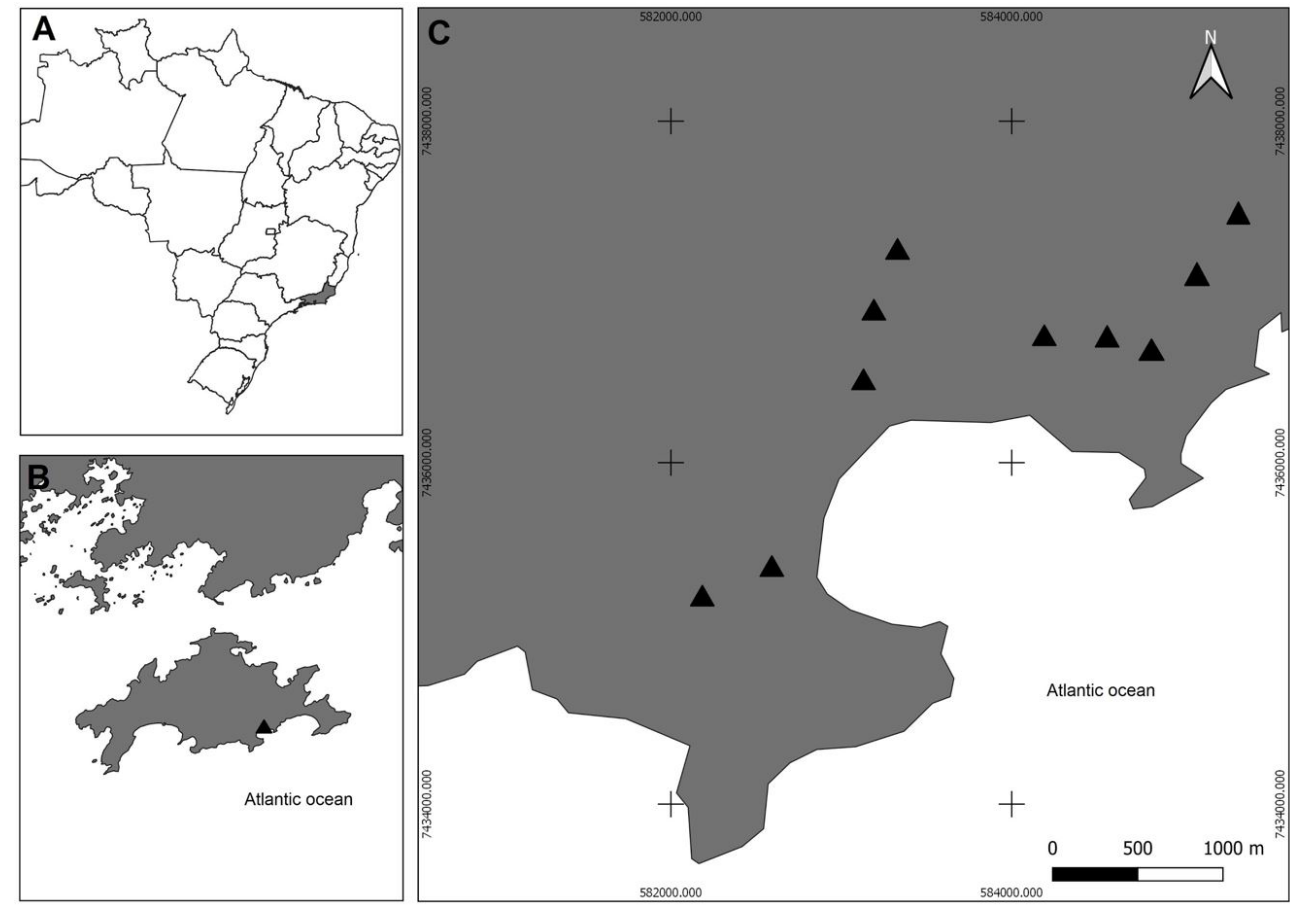

Figure 1. (A) Location of Rio de Janeiro State in Brazil; (B) Location of the study area in Ilha Grande; and (C) Location of each plot in Ilha Grande, Angra dos Reis, RJ, Brazil. 
trees were present, this definition was based on studies developed by the Laboratory of Mammal Ecology, which has monitored and evaluated the impact of jackfruit trees since 2006 (Raíces et al., 2008). The 10 plots with jackfruit trees measure $80 \times 80 \mathrm{~m}$ each and the plants were at least $200 \mathrm{~m}$ apart. All the individual jackfruit trees present on the plots with diameters at breast height $(\mathrm{DBH})$ above $15 \mathrm{~cm}$ were measured and marked, and their stem heights estimated (measure of the ground up to the first bifurcation).

\subsection{Treatments}

The jackfruit tree treatment took place in two distinct periods, 2009 and 2013. In 2009, two methods were applied, mechanical and chemical, in other words, 198 and 120 trees, respectively. In 2013, only the chemical method was applied at two different concentrations. In both periods, the treatment was applied only to individuals with $\mathrm{DBH}>15 \mathrm{~cm}$.

For the chemical treatment, it was applied to the trunk the active ingredient triclopyr, known by the trade name Garlon ${ }^{\circledR} 480^{\circledR}$ (Dow Agrosciense). Its selective and also systemic action mimic the plant growth hormone auxin, causing uncontrolled and disorganized growth in susceptible plant species, but the formulations are relatively non-toxic to terrestrial vertebrates and invertebrates (Tu et al., 2001). In Hawaii, triclopyr has been used successfully to control species such as blackwood acacia (Acacia melanoxylon), bush honeysuckle (Lonicera maackii), Chinese banyan (Ficus microcarpa), corkystem passionflower (Passiflora suberosa) and eucalyptus (Eucalyptus globulus). Cornish \& Burgin (2005) recommended the application of herbicides exclusively to the target plant by injection it into the trunk that is, reducing the risk of contamination.

In 2009, the mechanical and chemical treatments were applied to five plots each. The mechanical treatment consisted of making a ring, peeling a strip about $40 \mathrm{~cm}$ throughout the circumference of the tree in order to remove the phloem from the target plant (girdling). The ring, whenever possible and considering the ergonomic restrictions on the field worker, was made as close as possible to base of the tree, using a machete or axe, to a depth of at least $2 \mathrm{~cm}$ (Figure 2). For the chemical treatment, it was injected in a hole, $1 \mathrm{ml}$ of herbicide diluted in water at $2 \%$. The hole was sealed with spackling for wood.
In 2013, the herbicide was injected into untreated trees and into trees that survived the first treatment period. A $3 \mathrm{ml}$ volume of herbicide was injected per hole in two different concentrations, diluted in water at $6 \%$ and $8 \%$. One hole was drilled in the tree for every $10 \mathrm{~cm}$ of diameter (at a 1:10 ratio). A 14.4-volt battery-powered drill with a 9-mm-diameter iron drill was used to drill holes in the trunks. The herbicide was injected using a $50 \mathrm{ml}$ syringe, and after injection, the hole was sealed. A dye was used (Hi Light; Rigrantec Technology for Seeds and Plants S.A.) for visual control during the application, and the hole was sealed with a cut branch of Guarea guidonia (L.) of Meliaceae family.

\subsection{Statistical analysis}

The progress of treatments was evaluated following a protocol on phytosanitary conditions. It could be considered as a normal tree when it did not react to the treatment; senescent when it lost leaves and remained in decrepitude (from old age) due to the treatment and dead when it had no leaves, fruits or sprouts. Phytosanitary status was monitored at 60,150 and 240 days after
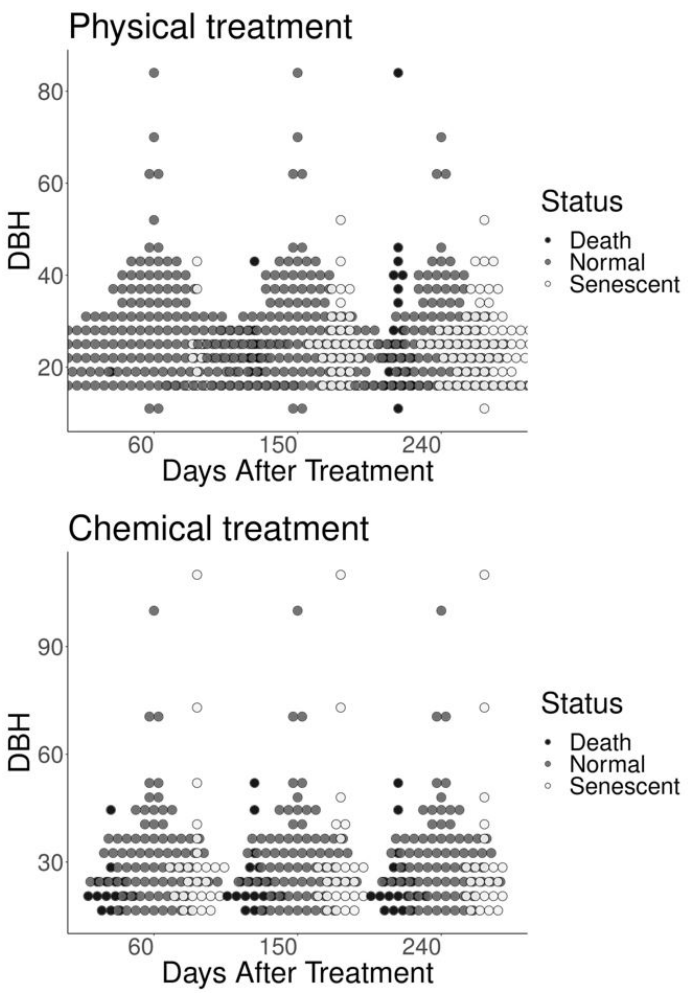

Figure 2. Relationship between Diameter at Breast Height (DBH) and the tree condition after 60, 150 and 240 days in the mechanical and chemical treatments. 
treatment intervention, and in the second treatment period, at 30, 60, 120, 210 and 310 days. The phytosanitary status was compared between and among mechanical and chemical treatments using analysis of variance (ANOVA), and among concentrations in the second treatment period. The analysis of phytosanitary condition of the trees (normal, senescent or dead) after mechanical and chemical treatments was related to the $\mathrm{DBH}$ by using the nonparametric Kruskal-Wallis test. The costs involved in each treatment method were calculated by recording the number of trees girdled or injected with herbicide per working day and also per person.

\section{RESULTS AND DISCUSSION}

Chemical and mechanical treatments began in October 2009 and were completed within approximately 12 months. A total of 85.6 man-hours were required to peel the trees' bark and 22.9 man-hours to inject the herbicide, of the 10 sampled plots and 318 treated trees. The mean $\mathrm{DBH}$ and height for treated trees were $28.2 \pm 12.4 \mathrm{~cm}$ and $9.4 \pm 3.5 \mathrm{~m}$, respectively. The mean basal area was $0.075 \pm 0.090 \mathrm{~m}^{2}$ per plot, with an average of $32 \pm 22$ adult trees with $\mathrm{DBH}>15 \mathrm{~cm}$ per plot.

\subsection{Comparison between treatments and among time periods $(2009 \times 2013)$}

\subsubsection{First period (2009)}

Regarding the sixty days from the beginning of the experiment, the mechanical and chemical treatments differed significantly (ANOVA, $\mathrm{df}=1, \mathrm{~F}=9.690$, $p=0.014)$. The proportion of individuals considered as normal was significantly lower referred to the chemical treatment. However, there was a slightly higher percentage of senescent trees in the chemical treatment after 60 days (ANOVA, df $=1, \mathrm{~F}=3.778$, $p=0.088$ ). A significantly higher proportion of dead trees was obtained with chemical treatment (ANOVA, $\mathrm{df}=1, \mathrm{~F}=9.001, p=0.017)($ Table 1$)$.

No difference was found between mechanical and chemical treatments after 150 days for normal (ANOVA, $\mathrm{df}=1, \mathrm{~F}=2,827, p=0.131$ ) and senescent states (ANOVA, df $=1 \mathrm{~F}=0.380, \mathrm{p}=0.555$ ). After 150 days, there was a significantly higher number of dead trees for chemical treatment (ANOVA, $\mathrm{df}=1$, $\mathrm{F}=15.72, p=0.004)$.

After 240 days, the number of trees in normal, senescent and dead stages did not differ significantly between these treatments (ANOVA, $\mathrm{df}=1, \mathrm{~F}=0.298$, $p=0.600 ; \mathrm{F}=1,193, p=0.307$ and $\mathrm{F}=0.961, p=0.356$, respectively).

The percentage analysis applied for normal individuals remaining after the experiment (60, 150 and 240 days) described a pattern of differential responses between these treatments. However, the response to chemical treatment occurred earlier (60 days) than the response to mechanical treatment. Mechanical treatment, in turn, presented a decrease in the number of trees considered normal over times, as these trees were inserted into senescent and dead classes.

\subsubsection{Second period (2013)}

In the second period, 30 days after using herbicide on the trunks of jackfruit trees, it could be observed a shift of individuals from normal into senescent category

Table 1. Results achieved by the mechanical and chemical methods at 60, 150 and 240 days after treatment.

\begin{tabular}{|c|c|c|c|c|}
\hline Phytosanitary & Mechanical & Chemical & $\mathbf{F}$ & $P$ value \\
\hline Conditions & \multicolumn{4}{|c|}{60 days } \\
\hline Normal & 186 & 79 & 9.690 & 0.014 \\
\hline Senescent & 10 & 26 & 3.778 & 0.088 \\
\hline \multirow[t]{2}{*}{ Dead } & 1 & 15 & 9.001 & 0.017 \\
\hline & \multicolumn{4}{|c|}{150 days } \\
\hline Normal & 157 & 75 & 2.827 & 0.131 \\
\hline Senescent & 33 & 26 & 0.380 & 0.555 \\
\hline \multirow[t]{2}{*}{ Dead } & 7 & 19 & 15.720 & 0.004 \\
\hline & \multicolumn{4}{|c|}{240 days } \\
\hline Normal & 104 & 77 & 0.298 & 0.600 \\
\hline Senescent & 70 & 23 & 1.193 & 0.307 \\
\hline Dead & 23 & 20 & 0.961 & 0.356 \\
\hline
\end{tabular}

Where $\mathrm{F}=\mathrm{F}$-distribution; $\mathrm{P}=\mathrm{p}$ value. 
at both concentrations tested (6\% and $8 \%)$ and in all treatments (Table 2). After 60 days of treatment, most of the treated trees were already senescent, and among those that were receiving the treatment for the second time (remnants), some trees were already dead. However, at 120 days of treatment, the number of dead trees increased substantially. The number of dead trees peaked at 210 days and did not differ between 210 and 310 days.

The effectiveness of chemical treatment (herbicide injection) at the concentrations used varied between $16 \%$ and $100 \%$ in these treatments tested in two periods (Table 3 ).

The first one corresponds to the first treatment period (2009), and the second one the number of days to the second treatment period (2013). There were no mechanical treatments in the second treatment period.

\subsubsection{Allometric relation}

Only in the first treatment period, the efficacy of the method was evaluated allometrically. The results of individual phytosanitary conditions, after mechanical treatment, had no significant relationship with $\mathrm{DBH}$ over 60 days $(p=0.415), 150$ days $(p=0.975)$ and 240 days $(p=0.804)$ (Figure $2 \mathrm{~A}$ and $2 \mathrm{~B}$ ). The response to chemical treatment in relation to $\mathrm{DBH}$ was positive and significant (Kruskal-Wallis, $p=0.009$ ) after 60 days. After 150 and 240 days of using chemical treatment (herbicide application) on the trunk, it could be noted that the response to chemical treatment was also influenced by DBH variable (Kruskal-Wallis $p=0.039$ and $p=0.013$, respectively).

There was no relation between jackfruit trees mortality and $\mathrm{DBH}$ regarding chemical concentration in 2013, in other others, the second period (Figure 3). Considering the trees that received the herbicide for the first time, only two surviving individuals belonged to the treatment that received the highest concentration of herbicide (8\%).

Mechanical treatment by girdling proved ineffective; in addition, this method required a higher work effort, being associated with a low mortality rate and therefore should not be considered for large areas, but only for small areas with few trees. In addition, the responses to mechanical treatment were much more time consuming and required more intensive follow-up, impacting on the operating costs of this control method.

Chemical treatment with triclopyr was sufficient for controlling jackfruit trees in Ilha Grande. Although, in

Table 2. Results achieved with the chemical method at 30, 60, 120, 240 and 310 days after treatment.

\begin{tabular}{|c|c|c|c|c|}
\hline $\begin{array}{c}\text { Phytosanitary } \\
\text { Conditions } \\
\end{array}$ & $\begin{array}{c}\text { First treatment } \\
6 \% \\
\end{array}$ & $\begin{array}{c}\text { Second treatment } \\
6 \% \\
\end{array}$ & $\begin{array}{c}\text { First treatment } \\
\qquad 8 \% \\
\end{array}$ & $\begin{array}{c}\text { Second treatment } \\
\mathbf{8 \%} \\
\end{array}$ \\
\hline \multicolumn{5}{|c|}{30 days } \\
\hline Normal & 12 & 6 & 1 & 2 \\
\hline Senescent & 19 & 25 & 30 & 33 \\
\hline Dead & 0 & 0 & 0 & 0 \\
\hline \multicolumn{5}{|c|}{60 days } \\
\hline Normal & 2 & 0 & 1 & 1 \\
\hline Senescent & 29 & 31 & 27 & 30 \\
\hline Dead & 0 & 0 & 3 & 4 \\
\hline \multicolumn{5}{|c|}{120 days } \\
\hline Normal & 0 & 2 & 2 & 1 \\
\hline Senescent & 20 & 15 & 11 & 24 \\
\hline Dead & 11 & 14 & 18 & 10 \\
\hline \multicolumn{5}{|c|}{210 days } \\
\hline Normal & 0 & 2 & 2 & 1 \\
\hline Senescent & 0 & 0 & 0 & 0 \\
\hline Dead & 31 & 29 & 29 & 34 \\
\hline \multicolumn{5}{|c|}{310 days } \\
\hline Normal & 0 & 2 & 2 & 1 \\
\hline Senescent & 0 & 0 & 0 & 0 \\
\hline Dead & 31 & 29 & 29 & 34 \\
\hline
\end{tabular}


Table 3. Treatments used to control jackfruit trees, number of trees treated and number of dead trees in each period.

\begin{tabular}{|c|c|c|c|c|c|c|c|}
\hline Treatment & $\begin{array}{l}\text { Trees } \\
\text { treated }\end{array}$ & $\begin{array}{l}\text { None/30 } \\
\text { days }\end{array}$ & $60 / 60$ days & $\begin{array}{l}150 / 120 \\
\text { days }\end{array}$ & $\begin{array}{l}240 / 210 \\
\text { days }\end{array}$ & $\begin{array}{l}\text { Survival } \\
\text { trees at } \\
\text { the end }\end{array}$ & $\begin{array}{c}\text { Effectiveness } \\
\text { of treatment } \\
(\%) \\
\end{array}$ \\
\hline \multicolumn{8}{|c|}{ Mechanical } \\
\hline Girdling & 198 & 0 & 1 & 7 & 23 & 174 & 12.1 \\
\hline \multicolumn{8}{|c|}{ Chemical } \\
\hline First treatment $2 \%$ & 120 & 0 & 15 & 18 & 20 & 100 & 16.6 \\
\hline Second treatment $6 \%$ & 31 & 0 & 0 & 11 & 20 & 0 & 100 \\
\hline $\begin{array}{l}\text { Remnants Second } \\
\text { treatment } 6 \%\end{array}$ & 31 & 0 & 0 & 13 & 16 & 2 & 93.5 \\
\hline Second treatment $8 \%$ & 31 & 0 & 3 & 18 & 8 & 2 & 93.5 \\
\hline $\begin{array}{l}\text { Remnants Second } \\
\text { treatment } 8 \%\end{array}$ & 35 & 0 & 4 & 9 & 22 & 1 & 97.1 \\
\hline
\end{tabular}
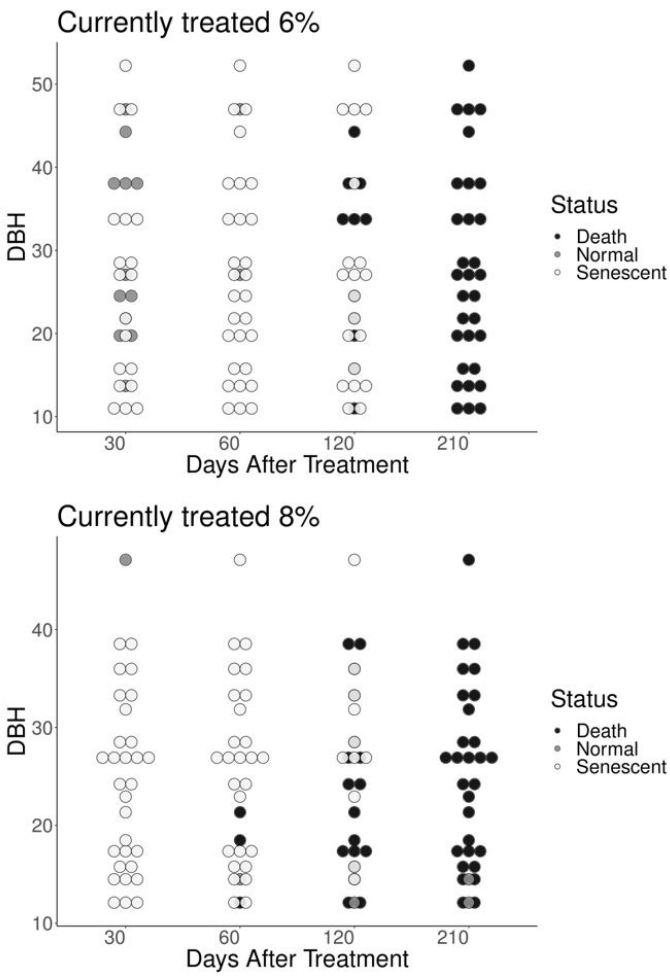

Figure 3. Relationship between Diameter at Breast Height $(\mathrm{DBH})$ and chemical treatment at the two dosages used in jackfruit trees.

the first treatment period, the proportion of dead trees obtained by chemical treatment at a concentration of $2 \%$ was not high (16.6\%), however, it was still greater than the results obtained with mechanical treatment (12\%).

In the second treatment period, the use of the active component at concentrations of $6 \%$ and $8 \%$ increased the results of dead trees to $100 \%$ and $93.5 \%$, respectively.
Indeed, selecting $2 \%$ concentration for tests in the first treatment period was parsimonious and conservative, in agreement with the recommendation of $\mathrm{Tu}$ et al. (2001), since it has been a pioneering experiment for environmentally important area.

The efficiency of mechanical treatment improved over times, and there was no difference among trees with different DBH which had the same treatment results. Nevertheless, the increase in the number of senescent trees over times did not necessarily result in an increase in dead trees. This is due to jackfruit trees high resistance and to the ability to sprout after suffering injury. Chemical treatment was shown to be more efficient in terms of the response time; however, there was an allometric effect, probably a consequence of under dosage in the first treatment period. Indeed, in the second treatment period, there was no allometric effect. The allometric effect can be used as an indicator of an inadequate dosage during the control of invasive species.

Although the diameter of the tree does not influence the effectiveness of mechanical treatment, operational factors may do it. In trees with large diameters, bark removal will be incomplete and neither deep nor wide bark removal have enough results to satisfactorily remove the phloem, due to worker fatigued, which demonstrates an advantage over chemical control of the species, whose costs are much lower and the efficiency greater.

In this scenario, it is emphasized that regardless of the chemical or mechanical control technique, the advantages of with the "standing death" is advantageous as quoted Lazzaro et al. (2019) that indicated that the 
non-opening of large clearings favors the recruitment of regenerating species.

The time lag of the experiment was adequate in both treatments, though Campos et al. (2002) stated that it is important to wait more than four months to determine whether the tree is dead or not. Despite the ecological and physiological differences between species, Campos et al. (2002) observed that with the cutting and brushing methods of Garlon ${ }^{\circledR} 480$, the trunks of A. dealbata and E. globulus responded satisfactorily after four months, with mortality rates of $100 \%$ and $88.5 \%$. A similar result (95\%) was found for the species A. melanoxylon (Santos \& Monteiro, 2007), using the same methodology as Campos et al. (2002). In the present study, the percentages of dead jackfruit trees after seven months were $16 \%$ with a triclopyr concentration of $2 \%, 100 \%$ and $93.5 \%$ for first-time treatments $(6 \%$ and $8 \%$ triclopyr concentrations, respectively), and $93.5 \%$ for those jackfruit trees treated a second time with $6 \%$ and $8 \%$ triclopyr concentrations, the percent mortality was $97.1 \%$.

An important factor to be considered is that other exotic opportunistic species are present in the forest or nearby areas, and this paradox must be taken into account, since a sudden change in these environments may favor the manifestation of a new invasive behaviour of those species, such as Dracaena fragans, Impatiens walleriana and Dieffenbachia picta. After controlling jackfruit trees, it could be observed the occupation of the area by individuals of Aphelandra prismatica, a species used in landscaping and in housing that had been abandoned for approximately 40 years. Biological material from invasive species may persist for years (Vilà \& Gimeno, 2007), indicating the need for monitoring for prevention of new invasions and interventions in the area where control of the target IAS was successful.

The jackfruit tree is a very abundant resource in Ilha Grande; in some places, such as in the "Caxadaço trail", where the present study was developed, its density is 270 individuals/ha (Bergallo et al., 2016). Each jackfruit tree can produce up to 100 fruits per year, with a mass that can vary from 4.5 to $30 \mathrm{~kg}$ and produce up to 500 seeds per fruit (Elevitch \& Manner, 2006). A frequent discussion regarding the control of jackfruit tree is the possibility of disturbing the associated fauna with food scarcity when the supply of fruits decreases. It is necessary to consider that the animals that feed on jackfruit trees previously consumed a diverse array of fruits and are now essentially restricted to these species (Abreu \& Rodrigues, 2010). It is important to emphasize that control must be done gradually, and it can be considered that there are diverse food resources for the well-known small mammal community in the forest.

\section{CONCLUSIONS}

As a priority action, the control of $A$. heterophyllus individuals should be directed primarily to individuals in the adult phase, which is mature and fruiting, with $\mathrm{DBH}>15 \mathrm{~cm}$, to maximize effort and the application of resources to control. However, uprooting seedlings and cutting down individuals smaller than $15 \mathrm{~cm}$ should be also considered. In this sense, it is recommended to designate areas with low densities and with a random distribution pattern.

We believe that the control of jackfruit tree populations is a pressing issue, and eradication may be possible (Simberloff, 2001), albeit unlikely, however, solutions for the management of conservation areas must be accepted and understood by society in order to establish control methods as a long-term strategy and finally, to accomplish eradication.

\section{ACKNOWLEDGEMENTS}

We would like to thank the director of Ilha Grande State Park and the administration of CEADS - UERJ (Universidade do Estado do Rio de Janeiro) for the authorizations and logistics support.

\section{SUBMISSION STATUS}

Received: 12 june, 2019

Accepted: 3 nov., 2019

\section{CORRESPONDENCE TO}

\section{Ciro José Ribeiro de Moura}

Universidade Federal do Rio de Janeiro - UFRJ,

Av. Athos da Silveira Ramos, 149, Bloco A, Cidade Universitária, CEP 21941-909, Rio de Janeiro, RJ, Brasil

e-mail: cirojrm@hotmail.com 


\section{FINANCIAL SUPPORT}

Conselho Nacional de Desenvolvimento Científico e Tecnológico (Grant/Award Number: '307715/2009-4'). Fundação Carlos Chagas Filho de Amparo à Pesquisa do Estado do Rio de Janeiro (Grant/Award Number: 'E-26/103.016/2011')

\section{REFERENCES}

Abreu RCR, Rodrigues PJFP. Exotic tree Artocarpus heterophyllus (Moraceae) invades the Brazilian Atlantic Rainforest. Rodriguésia 2010; 61(4): 677-688. http://dx.doi. org/10.1590/2175-7860201061409.

Bergallo HG, Bergallo AC, Rocha HB, Rocha CFD. Invasion by Artocarpus heterophyllus (Moraceae) in an island in the Atlantic Forest Biome, Brazil: distribution at the landscape level, density and need for control. Journal of Coastal Conservation 2016; 20(3): 191-198. http://dx.doi. org/10.1007/s11852-016-0429-9.

Boni R, Novelli FZ, Silva AG. Um alerta para os riscos de bioinvasão de jaqueiras, Artocarpus heterophyllus Lam., na Reserva Biológica Paulo Fraga Rodrigues, antiga Reserva Biológica Duas Bocas, no Espírito Santo, Sudeste do Brasil. Natureza On Line 2009; 7: 51-55.

Cáceres NC. Population ecology and reproduction of the white-eared opossum Didelphis albiventris (Mammalia, Marsupialia) in an urban environment of Brazil. Ciência e Cultura. 2000; 52: 171-174.

Campos J, Rocha ME, Tavares M. Controlo de acácias com fitocidas nas dunas do litoral. Silva Lusitana 2002; 10: 201-206.

Cornish PS, Burgin S. Residual effects of glyphosate herbicide in ecological restoration. Restoration Ecology 2005; 13(4): 695-702. http://dx.doi.org/10.1111/j.1526100X.2005.00088.x.

Elevitch CR, Manner HI. Artocarpus heterophyllus (jackfruit). In: Elevitch CR, editor. Species profiles for Pacific Island Agroforestry. Hawaii: Permanent Agriculture Resources; 2006. p. 1-17.

Fabricante JR, Araújo KCT, Andrade LA, Ferreira JVA. Invasão biológica de Artocarpus heterophyllus Lam. (Moraceae) em um fragmento de Mata Atlântica no Nordeste do Brasil: impactos sobre a fitodiversidade e os solos dos sítios invadidos. Acta Botanica Brasílica 2012; 26(2): 399-407. http://dx.doi.org/10.1590/S010233062012000200015 .

Hierro JL, Maron JL, Callaway RM. A biogeographical approach to plant invasions: the importance of studying exotics in their introduced and native range. Journal of Ecology 2005; 93(1): 5-15. http://dx.doi.org/10.1111/j.00220477.2004.00953.x.
Invasive Species Advisory Committee - ISSAC. Invasive species definition clarification and guidance white paper [online]. Washington: U.S. Department of the Interior; 2018 [cited 2018 Dec 19]. Available from: http://www. invasivespecies.gov/global/ISAC/ISAC_documents/ ISAC\% 20Definititions\% 20White\% 20Paper20/

Itou T, Hayama K, Sakai A, Tanouchi H, Okuda S, Kushima $\mathrm{H}$ et al. Developing an effective glyphosate application technique to control Bischofia javanica Blume, an invasive alien tree species in the Ogasawara Islands. Journal of Forest Research 2014; 20(1):248-253. http://dx.doi.org/10.1007/ s10310-014-0457-y.

Khan ML. Effects of seed mass on seedling success in Artocarpus heterophyllus L., a tropical tree species of north-east India. Acta Oecologica 2004; 25(1-2): 103-110. http://dx.doi.org/10.1016/j.actao.2003.11.007.

Lazzaro LG, Esteves R, Souza SCPM, Ivanauskas NM. Técnicas para controle químico de palmeiras invasoras em Unidade de Conservação na região metropolitana de São Paulo. Biotemas 2019; 32(2): 55-70. http://dx.doi. org/10.5007/2175-7925.2019v32n2p55.

Mello JHF, Moulton TP, Raíces DSL, Bergallo HG. About rats and jackfruit trees: modeling the carrying capacity of a Brazilian Atlantic Forest spiny-rat Trinomys dimidiatus (Günther, 1877) - Rodentia, Echimyidae-population with varying jackfruit tree (Artocarpus heterophyllus L.) abundances. Brazilian Journal of Biology $=$ Revista Brasileira de Biologia 2015; 75(1): 208-215. http://dx.doi. org/10.1590/1519-6984.11613. PMid:25945639.

Moody ME, Mack RN. Controlling the spread of plant invasions: the importance of nascent foci. Journal of Applied Ecology 1988; 25(3): 1009-1021. http://dx.doi. org/10.2307/2403762.

Myers JP, Antoniou MN, Blumberg B, Carroll L, Colborn T, Everett LG et al. Concerns over use of glyphosate-based herbicides and risks associated with exposures: a consensus statement. Environmental Health 2016; 15(1): 19. http:// dx.doi.org/10.1186/s12940-016-0117-0. PMid:26883814.

Oliveira R. Ação antrópica e resultantes sobre a estrutura e composição da Mata Atlântica na Ilha Grande, RJ. Rodriguésia 2002; 53(82): 671-676. http://dx.doi. org/10.1590/2175-78602002538203.

Pimentel D. Biological invasions: economic and environmental costs of alien plant, animal, and microbe species. 1st ed. Florida: CRC Press; 2002.

Pyšek P, Jarošík V, Hulme PE, Pergl J, Hejda M, Schaffner $\mathrm{U}$ et al. A global assessment of invasive plant impacts on resident species, communities and ecosystems: the interaction of impact measures, invading species' traits and environment. Global Change Biology 2012; 18(5): 17251737. http://dx.doi.org/10.1111/j.1365-2486.2011.02636.x. RADAMBRASIL. SF. 32/24: geologia, geomorfologia, pedologia, vegetação e uso potencial da terra: Ministério 
das Minas e Energia, Rio de Janeiro/Vitória. Rio de Janeiro: IBGE; 1993. (Levantamento de Recursos Naturais; no. 32).

Raíces DS, Ferreira PM, Mello JHF, Bergallo HG. Smile, you are on camera or in a live trap! The role of mammals in dispersion of jackfruit and native seeds in Ilha Grande State Park, Brazil. Nature Conservation Research 2017; 2(4): 78-89. http://dx.doi.org/10.24189/ncr.2017.045.

Raíces DSL, Pessôa FS, Luz JL, Jordão-Nogueira T, Esbérard CEL, Bergallo HG. Feeding behaviour of the bat Phyllostomus hastatus (Pallas 1767) in jackfruit, Artrocarpus heterophyllus Lamarck (Moraceae), in Ilha Grande, Rio de Janeiro, Brazil. Revista Brasileira de Zoociências 2008; 10: 265-267.

Rejmánek, M., \& Pitcairn, M. J. When is eradication of exotic pest plants a realistic goal? In: Vietch CR, Clout $\mathrm{MN}$, editors. Turning the tide: the eradication of invasive species. Cambridge: IUCN; 2002. p. 249-253.

Richardson DM, Thuiller W. Home away from home: objective mapping of high-risk source areas for plant introductions. Diversity \& Distributions 2007; 13(3): 299312. http://dx.doi.org/10.1111/j.1472-4642.2007.00337.x.

Santiago AM, Guimarães C, Nogueira I, Santos MS, Sant'anna T. História da Ilha Grande e Patrimônio cultural material e imaterial. In: Bastos $\mathrm{M}$, Callado $\mathrm{CH}$, editors. O ambiente da Ilha Grande. Rio de Janeiro: Centro de Estudos Ambientais e Desenvolvimento Sustentável; 2009. p. 299-365.

Santos AR, Monteiro A. Controlo de invasoras lenhosas no Parque Ecológico do Funchal. Silva Lusitana 2007; 15(2): 249-255.

Sher AA, El Waer H, González E, Anderson R, Henry AL, Biedron $\mathrm{R}$ et al. Native species recovery after reduction of an invasive tree by biological control with and without active removal. Ecological Engineering 2018; 111: 167-175. http://dx.doi.org/10.1016/j.ecoleng.2017.11.018.

Shine C. A toolkit for developing legal and institutional frameworks for invasive alien [online]. Nairobi: Global Invasive Species Programme; 2008 [cited 2018 Sept 25]. Available from: http://www.issg.org/pdf/publications/ gisp/guidelines_toolkits_bestpractice/shine_2008_en.pdf

Sigg J. The role of herbicides in preserving biodiversity. Fremontia 1998; 26: 65-67.

Simberloff D. Eradication of island invasives: practical actions and results achieved. Trends in Ecology \& Evolution 2001; 16(6): 273-274. http://dx.doi.org/10.1016/S01695347(01)02154-1.

Tu M, Hurd C, Randall JM. Weed control methods handbook: tools \& techniques for use in natural areas. Athens: University of Georgia; 2001.

Vilà $\mathrm{M}$, Gimeno I. Does invasion by an alien plant species affect the soil seed bank? Journal of Vegetation Science 2007; 18: 423-430.

Weber E. Invasive plant species of the world: a reference guide to environmental weeds. Wallingford: CABI; 2017. http://dx.doi.org/10.1079/9781780643861.0000.

Williamson MH, Fitter A. The characters of successful invaders. Biological Conservation 1996; 78(1-2): 163-170. http://dx.doi.org/10.1016/0006-3207(96)00025-0.

Zenni RD, Dechoum MS, Ziller SR. Dez anos do informe brasileiro sobre espécies exóticas invasoras: avanços, lacunas e direções futuras. Biotemas 2016; 29(1): 133-153. http://dx.doi.org/10.5007/2175-7925.2016v29n1p133.

Ziller SR. Os processos de degradação ambiental originados por plantas exóticas invasoras. Ciência Hoje 2001; 30. http://dx.doi.org/10.1590/S0102-261X2008000200004. 